\title{
PROFILING THE VOCABULARY OF NEWS TEXTS AS CAPACITY BUILDING FOR LANGUAGE TEACHERS
}

\author{
Gusti Astika \\ Universitas Kristen Satya Wacana, Salatiga, Indonesia \\ email: gustiastika@yahoo.com
}

Article received: 7 August 2014

Final proof received: 17 December 2014

\begin{abstract}
The importance of vocabulary in reading has been discussed extensively in the literature. Researchers claim that vocabulary is essential and has a central role in comprehension. Development in ICT and easy access to information from the internet necessitate language teachers to have relevant knowledge and skills to utilize pedagogical tools to use authentic online materials for learning purposes. One of such a tool is the Vocabulary Profiler that can be used to categorize lexical words in a text into different frequency levels: high, low, and academic word list. This paper discusses how to use the Vocabulary Profiler to classify words in a text into the different categories. The utilization of this tool can significantly alleviate the workload of teachers in selecting vocabulary in reading text which is conventionally based on teachers' intuition and perception. The sample text in this paper was selected from VOA website which may not be found in the textbooks currently used at schools. The paper ends with some implication for teaching about vocabulary selection.
\end{abstract}

Keywords: vocabulary profiler, capacity building, learning strategy

Teachers' life in the $21^{\text {st }}$ century is marked by easy access to an abundance of information, print and digital, rapid development of technology devices, and the need for collaboration, innovation, and contribution (Information, Media and Technology Skills, 2014). To be able to survive in the life in the $21^{\text {st }}$ century, people in all walks of life including those involved in the educational sectors must be able to acquire and possess a range of skills that are functional to utilize information, media, and technology. In order to utilize information, one has to be information-literate, which means being able to access information quickly from a variety of sources and being able to evaluate information critically and being able to use the information to solve problems at hand.

Students in the $21^{\text {st }}$ century are characterized by those who are prepared for the complexity of life and academic environment and those who are not (Learning and Innovation Skills, 2014). Academic life in the $21^{\text {st }}$ century requires students to possess creativity, critical thinking skills, and collaboration skills. Creativity refers to being able to use a wide range of ideas and techniques in dealing with problems. Critical thinking refers to being able to use different types of reasoning, inductive, deductive, which are appropriate to use in a particular situation. Collaboration skills refer to an ability to work effectively with other people with flexibility and respect.

Educational system should equip students with creativity, critical thinking, and collaborations which are referred to as $21^{\text {st }}$ century skills (Ananiadou, K. and Claro, M. (2009). In the educational system where knowledge is highly valued, students as well as teachers must be able to process and organize information and transform it to produce new ideas. In preparation of students to be lifelong learners, the skills to communicate play an important role in order to function effectively as members of larger communities. In this regard, the use of ICT can not be overlooked since it is vital to exchange, evaluate, and present information in today's digital era.

In order to meet the challenges of the $21^{\text {st }}$ century, capacity building innovations for English language teachers have to be created. In the past, capacity building was equated with training in which people went through the process of learning a particular skill in order to do a job. Now, capacity building has gone beyond training people, which includes development of institution or improvement of organization (Wehmeier, 2000). Capacity building may take different forms such as pre- 
service training or in-service training (Arikawei and Pelesai ,2014). The forms and process of capacity building in the $21^{\text {st }}$ century should be directed to the acquisition of skills and competencies which enable people to function effectively in their professional workplace. Among many issues in language education in Asia, educational leaders have identified three critical issues: development needs of English teachers, access to language education, and application of online education (Kimura, 2013). According to the report, the existing foreign language proficiency gap among learners in many parts of Asia, including Indonesia, may have been caused by uneven access to language education. While the common practice to look for answers to this educational gap is to seek help from the government, language educators may have innovative solutions to address the gap through capacity building and trainings for language teachers. In particular, English language teachers will have a significant role to play do develop learners' language proficiency in order to equip them with the necessary skill to communicate using English as an international lingua franca (House, 2012; Kirkpatrick, 2010). In many different sectors of employment, there is a clear need for English language proficiency. However, in preparation of learners to anticipate global competition in the job market, we need to ask if English language proficiency alone is sufficient. Increased hours of instruction in English may help learners to become more proficient, but other skills which are much in demand in the era of competitive global job market is intercultural communicative competence (Stroupe, 2013) which requires long term and continuous educational efforts and endeavor to develop students' understanding and empathy for others of different cultural groups.

\section{WHY VOCABULARY IS ESSENTIAL}

Learning vocabulary is one of the components in language teaching that is essential to reading comprehension. With sufficient vocabulary knowledge, learners will be able to access knowledge, express ideas, communicate, and learn new concepts. Much research on vocabulary acquisition has found out that there is a high correlation between word knowledge and reading comprehension (Sedita, 2005). According to Hirsch (2003), the learner needs to know about $90-95 \%$ of the words in a text in order to comprehend it. This amount of word knowledge can be reached through a four-part program advocated by Graves (2000) that includes wide reading, teaching individual words, teaching word learning strategies, and fostering word consciousness. This program underlines the significance of providing learners with the opportunities for extensive reading and vocabulary learning strategy programs. Stahl (2003) and Schmitt (2010) pointed out that vocabulary knowledge improves gradually and incrementally from vague understanding of word meaning to full meaning of word knowledge. This notion of gradual vocabulary acquisition fits well with the concept of designing extensive reading programs in which learners can expand their word knowledge. However, the question remains: how much exposure is necessary to ensure learning of vocabulary. Webb (2007) found out that sufficient amount of exposure is affected by a number of variables, among others are learning strategies (intentional or incidental), type and amount of input (textual or aural), purpose of reading (for information or entertainment), learning context (first, or foreign language). For learners in an EFL environment such as that in Indonesian schools, the only source of input for vocabulary development is, to a large extent, from reading sources necessary for receptive vocabulary knowledge. The suggestion from Schmitt (2000) is worth following. He suggests that at early stages of learning, students should learn about 1000-2000 high-frequency words and then increase to about 3000-5000 word families necessary to read authentic texts that may include academic words for reading texts at university level. In his latest edition (Schmitt, 2010) he suggests that teachers do not have to teach every word in the text. Any other words will have to be left to the students to learn them through any form of exposure; particularly helpful is exposure through extensive reading.

The importance of teaching vocabulary has been widely acknowledged. Knowledge of words is used to access background knowledge, express ideas and communicate with people (Sedita, 2005). Academic success is closely linked to word knowledge students have. With extensive vocabulary students will understand ideas and concepts they learn more effectively. In fact, there is a high correlation between word knowledge and reading comprehension (Sedita, 2005). Comprehension of text requires knowing at least $90-95 \%$ of the words in the text (Hirsch, 2003) and word knowledge of the learners improves incrementally (Stahl, 2003), therefore, 
it is crucial that vocabulary instruction should provide learners with multiple exposures of vocabulary. When learners' vocabulary improves, it in turns improves their ability to read. According to Nation (2001) in addition to the first 2000 high-frequency words, students at university level should acquire academic words at the advanced level used in a different context.

\section{PROBLEMS AND STRATEGIES IN TEACHING VOCABULARY}

The challenges encountered by teachers in teaching vocabulary and by learners in learning it have been widely discussed in the literature. One constraint in classroom practice is an insufficient amount of time and opportunities to use it (Hunt \& Beglar, 2005; Schmitt, 2008). Thus, according to Eckerth and Tavakoli (2012), it is necessary to provide students with extensive exposure to both textual and aural input materials that may lead to promote learners' knowledge of vocabulary. Extensive exposure of vocabulary input can overtime develop retention of word meaning. It needs to note that learners have more difficulty with developing productive vocabulary than receptive vocabulary (Zheng, 2012) and that this development process is incremental (Schmitt, 2000). Therefore, this has to become the attention of teachers that vocabulary development is a long-term process especially noticeable in an acquisition-poor EFL context that may be found in school contexts in Indonesia. Such an environment can not provide learners with adequate opportunity to use English words they learn in class. This condition, in turn, may weaken their motivation to develop communicative skills because their language learning outside class is not socially functional; hence, their vocabulary development may be diminishing.

Strategies for teaching vocabulary have appeared in many publications, and various techniques of teaching vocabulary can be classified into three categories: explicit, incidental, and a combination of both (Hunt \& Beglar, 2002). Schmitt (2010, 120-121) describes that explicit learning focuses attention directly on the words being learned, and incidental learning takes place when the learner is using the word for communicative purposes. Explicit learning is more quickly, but it would take too much time and effort to learn an adequate size of vocabulary. On the other hand, incidental learning is a slow process and gradual, and requires quite some time to use a particular word especially if it infrequently occurs. The middle way out is to combine the two approaches, and they should be used complementarily because both approaches are necessary for acquisition.

The choice of any strategy may depend on many factors, one of which is the student characteristics that could be influenced by their learning culture. Meyer (2012) contrasted characteristics of Asian and western learners about their learning, showing the extent to which both groups exhibit different types of independence or responsibility for their own learning. Asian learners are described as quiet, reticent, dependent on teachers, and western learners are quite the opposite. With the new 2013 school curriculum released by the Indonesian Ministry of Education and Culture, we may hope that the process of teaching and learning English in Indonesian schools will be more student-centered. The curriculum provides much room to both teachers and students to broaden learning strategies through group work and autonomous learning. If correctly implemented, it will give more freedom to learners and control over their choice of materials and activities which may improve their intrinsic motivation for learning.

The spirit of the 2013 school curriculum is aligned with the principles of task-based language teaching (Willis, 1996; \& Willis and Willis, 2012) in which learning task is sequenced from pre-task, task cycle, report, and language focus, with greater role is given to students to achieve learning goal, that is active use of English. With task-based language learning, the opportunities for meaningful language learning can be created both inside and outside classroom. With the advancement of ICT, autonomous active learning can be created through tasks which can make learners interact to each other using language they have learned. According to Nunan (2004) learning a language through tasks can bring learners to interactive meaningful use of language which is more important than practice on language structures. Teaching English with task-based framework advocated by Willis \& Willis (2012) gives ample opportunities to use vocabulary in meaningful communicative activities utilizing multiple sources of information.

\section{THE INTERNET AND VOCABULARY LEARNING}


With the continuous progress of the internet and its easy access to information, the temptation of use internet materials and integrate it into language teaching has been increasing. The internet has many useful applications for language teaching and (semi) authentic materials that can be used as alternatives to more traditional published materials. The internet has exerted its role as information provider, communication tool, and social media. Among many useful websites that provide English language learning materials, is Voice of America's Learning English (www.learningenglish.voanews.com). This website offers semi-authentic content of current events that are updated daily. The text in VOA news contains approximately 1500 words with audio or video component narrated at a reduced speed approximately on-third of ordinary speech. The text file with its audio or video can be downloaded for English learning purposes.

Although digital media as a mode of delivering English lessons are conveniently available, the use of such media should not be regarded as teaching methodology (Chinnery, 2014) that replaces the presence of the teacher in the classroom. In our school context, where English is a foreign language, the presence of a teacher is essential to create authentic interaction and authentic learning. Although the internet offers many advantages for English learning, there are some crucial issues that need to be taken into account when it is integrated into English learning. English language teachers are now overloaded with teaching and administrative work, and they may feel reluctant to incorporate new ideas and materials into their tight work schedule. Some teachers may lack confidence in using internet resources and integrate them into classroom activities. At the school level, there may also be budgeting constraints and inadequate resources for the students, not to mention the cost of computer lab maintenance. The study by Al-Maini (2013) noted that teachers in his study had resistance to the use of ICT, their participation in in-service training was limited, and their teacher-centered perception of teaching persisted. This study shows that the teachers seem to be unwilling to depart from their familiar way of teaching and go beyond their pedagogical comfort zone.

With a continuous development of ICT and computer technology, the media that can be utilized for English learning will be more userfriendly, and useful teaching materials from the internet will abound. In order to make maximal use of this technology, teachers must acquire some skills and some degree of confidence in using computer and some understanding of the potentials that computers have for English language learning. It is a common sight that more and more students and teachers today use digital devices such as mobile phones and tablets to communicate and google information from the internet. It is no doubt that in the future mobile technology will play an important role in English language teaching and learning, and, therefore, this phenomena should make teachers excited to integrate digital materials and technology into language learning activities both inside and outside the classroom. This integration will provide students with language learning resources that are not always dependent on textbooks available from the school and language learning activities may not always be confined to classroom walls.

\section{VOCABULARY PROFILER}

The vocabulary that learners are required to learn may expose different degree of learning burden depending on word-internal factors such as forms, cognateness, abstractness, and word length (Milton, 2009). Vocabulary that learners learn is not only determined by frequencies but also the themes that are used in the materials or texts. In other words, thematically important words may be learned at the same time as words that belong to high-frequency word group (Milton, 2009). This perspective is somewhat deviating from the common assumption that high-frequency words are learned earlier than low-frequency words (Laufer \& Nation, 1995). Thematic vocabulary fall under low-frequency word group and in classroom settings very often learning thematic vocabulary can not be avoided because they are in the course materials. It is very likely that course materials and individual factors also contribute to vocabulary acquisition other than frequency, even from early years of English learning.

Learner vocabulary production and vocabulary contained in course materials can be measured by means of vocabulary profiler, a computer program developed by Tom Cobb (www.lextutor.ca/vp). This program was developed from Lexical Frequency Profile (LFP) originally designed by Laufer and Nation (1995) that can be used to determine lexical richness (lexical difficulty). In order to use the program, a text is copied into the program and then the 
analysis will show the percentages of type/token ratio of word families according to the four frequency levels. This program classifies words of a text as first 1000 most frequent word families, second 1000 most frequent word families, and the Academic Wordlist. With this program, the lexical profile of a text may comprise $80 \%$ of words in the text belong to the first group, $10 \%$ of words belong to the second group, and 5\% belong to the Academic Wordlist. The remaining 5\% do not belong to any group, labeled as 'Off-List'. Thus, a text that contains a high proportion of Academic Wordlist may require a high level of lexical proficiency.

A widely accepted approach to identify words that cause difficulty for learners is to determine its frequency using lexical profiling. This tool has been used all over the world to determine word frequency quickly (Cobb, 2010). With this tool, words with lower frequency can be identified quickly. Low-frequency words are the source of difficulty in learning vocabulary. In other words, high-frequency words are learned earlier, which Milton (2007) describes as 'frequency model of learning' (Milton, 2007, p.48). High-frequency words are easier to acquire because its production is more automatic than the production of low-frequency words (Bybee, 2002). Below is the output of the Vocabulary Profiler using a news text from VOA website as input.

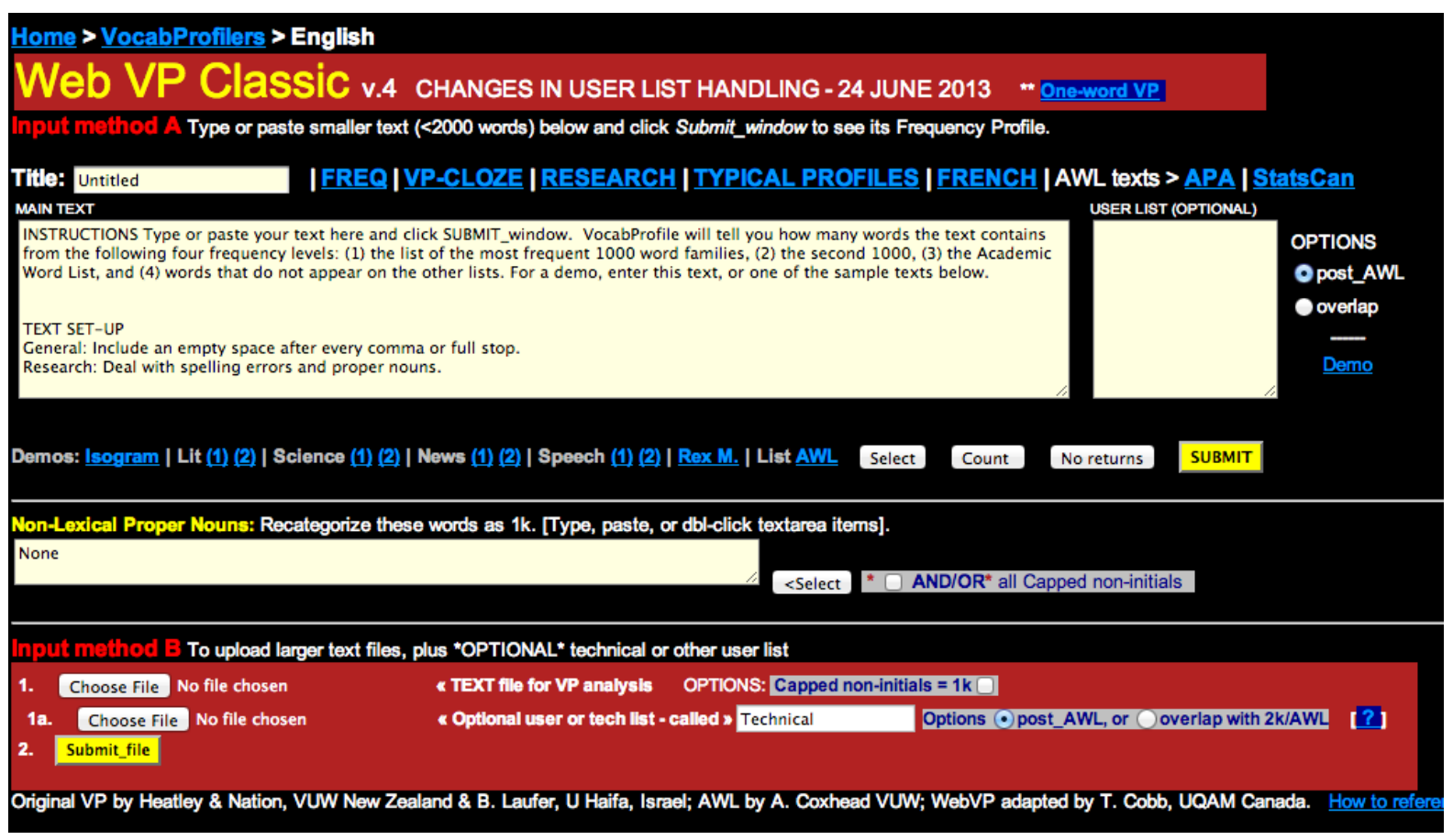

Figure 1. Screenshot of Vocabulary Profiler

Figure 1 is the screenshot of Vocabulary Profiler at http://www.lextutor.ca/vp/eng. In the middle of the profiler, there are some instructions for pasting text into the tool. Then, submit it for automatic analysis by hitting the button 'SUBMIT' below the right corner of the space. 


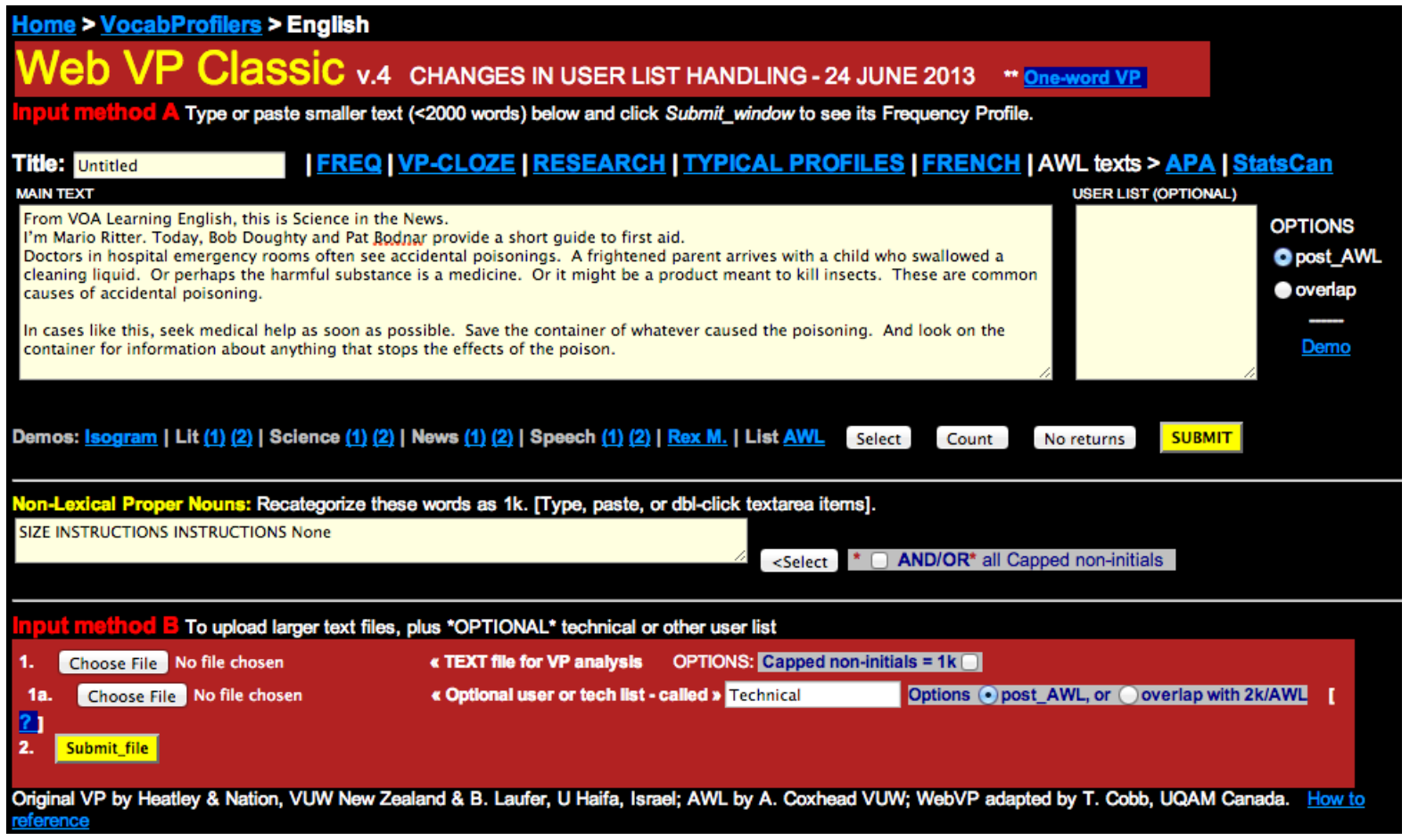

Figure 2. Vocabulary Profiler with news text

Figure 2 shows a portion of a text, 1461 words long, copied from

http://learningenglish.voanews.com/content/first -aid-cpr-defibrillator/1946462.html and pasted into the tool. Below is the output that shows the vocabulary profile of the text.

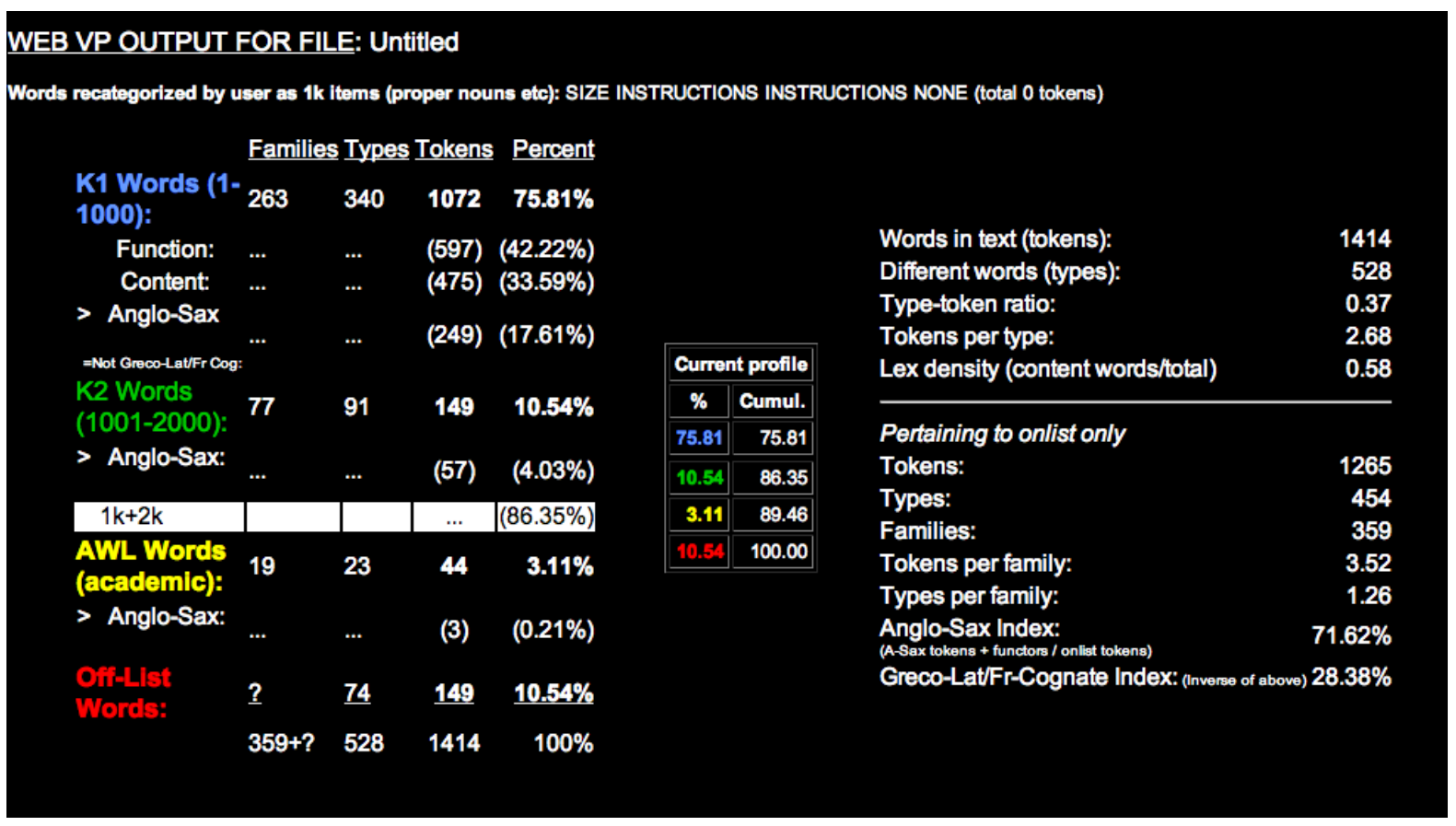

Figure 3. Output of Vocabulary Profiler 
As seen in Figure 3, the summary table in the middle shows that $75,81 \%$ of the words in the text fall into K1 word group; that is the first 1000 most frequent words. $10,54 \%$ fall into $\mathrm{K} 2$ word group; that is the second 2000 most frequent words, and $3,11 \%$ belong to AWL
(Academic Word List) group. The rest 10,54\% are 'Off-List Words' that can not be classified into any three groups. The summary table also shows the accumulative percentages of the group frequencies. The word frequency classification of the text is presented in Appendix 2.
From VOA Learning English, this is Science in the News. I'm Mario Ritter. Today, Bob Doughty and Pat Bodnar provide a short guide to first aid.

Doctors in hospital emergency rooms often see accidental poisonings. A frightened parent arrives with a child who swallowed a cleaning liquid. Or perhaps the harmful substance is a medicine. Or it might be a product meant to kill insects. These are common causes of accidental poisoning.

In cases like this, seek medical help as soon as possible. Save the container of whatever caused the poisoning. And look on the container for information about anything that stops the effects of the poison.

Save anything expelled from the mouth of the victim. That way, doctors can examine it.

In the past, some people forced poisoning victims to

empty the stomach. They used a liquid -- syrup of ipecac - to do this. But a leading medical organization no longer advises parents to keep syrup of ipecac. The American Academy of Pediatrics says some poisons can cause additional damage when they come back up the throat.

Millions of people know how to give abdominal thrusts to save a person choking on something trapped in the throat.

The American Red Cross says a rescuer should first hit the person on the back five times between the shoulder bones. These back blows may ease the choking. If the airway is still blocked, the Red Cross suggests pushing hard five times along the victim's abdomen. The

abdomen is the area between the chest and the hipbones.

You can do these abdominal thrusts by getting directly behind a sitting or standing person. Put your arms

arnund the virtim's waist Clnce nne hand to form a hall

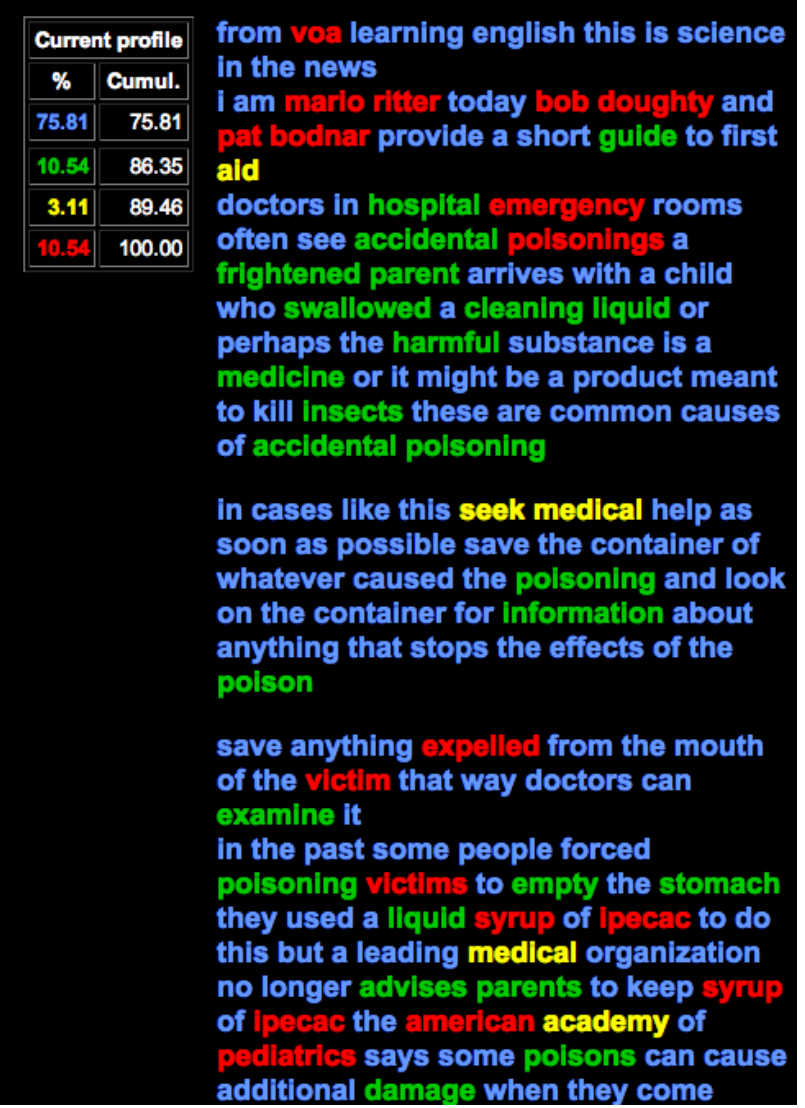

Figure 4. Original and profiled texts

Figure 4 displays side by side the original and the output texts with four different colors. Words in blue are those words that belong to the first 1000 word group, words in green belong to the second 1000 word group, words in yellow are academic word group, and words in red are 'OffList' words. In the webpage of the output, the text can be scrolled up and down showing all words in the text in different colors. The table in the middle shows the proportions of words that belong to each frequency group, from the high 1000-word frequency to the low-frequency group of the academic words and off-list words.

Overall, the profiler provides useful information and practical guide to teachers for vocabulary selection about vocabulary difficulty level. As displayed in Figure 4, the academic words and 'Off-List' words would present most problems to students and these are the words that should get more attention of teachers in designing vocabulary practice because they fall under the category of low-frequency word groups.

\section{IMPLICATIONS FOR TEACHING VOCABULARY}

Prior to the 1970s, language teaching was dominated by Grammar-Translation and Audiolingual Methods which emphasized accuracy of language structures through explicit teaching of rules and memorization (Huang, 2010). Then, arouse Communicative Language Teaching (CLT) due to dissatisfaction of CLT which gave more attention to fluency at the expense of accuracy. In response to the drawback of CLT, Long (1991) proposed form- 
focus instruction which focuses on meaning and communication with attention to grammar elements when the need for communication repair occurs. This elicited attention to form may also include elements of vocabulary. Thus, a focus-on form approach does not neglect accuracy of structures or vocabulary. Since the adoption of CLT, there have been a number of its manifestations, on of which is Task-Based Language Teaching (Nunan, 2004). This approach recognizes the importance of fluency and accuracy which are nicely integrated in a task framework developed by Willis \& Willis (2012) into a series of task sequences throughout the task completion such as priming, planning, report, and form-focus work.

As discussed previously, the output from the vocabulary profiler provides useful mapping of words in the text. As can be observed in Appendix 2, the vocabulary in the text selected for the profiler has been classified into four: K1 words (the first 1000-word group), K2 words (the second 2000-word group), Academic word group, and Off-list word group. With this classification, teachers will be able to decide what frequency level they would like students to work on and what pedagogical activities are planned. One suggestion for developing students' acquisition of vocabulary is to apply the principles of Task-Based Language Teaching that aims not only to develop students' implicit knowledge but also procedural knowledge of vocabulary through communicative task activities. Thanh \& Huan's study (2012) on the impact of task-based language learning on vocabulary acquisition of Vietnamese college students shows that the students' vocabulary achievement and motivation to learn English improved after their experiment. This is one of many studies that has demonstrated the effectiveness of task-based language teaching in English language learning.

\section{CONCLUSION}

This paper has described the challenges that the $21^{\text {st }}$ century brings to language educators and the skills needed to cope with the demands of the $21^{\text {st }}$ century in English language teaching. The continuous advancement of the internet technology, ICT, and digital devices has exerted its influence on the job and responsibility of language teachers. Now they have to be on the move technologically and align their professional skills with the requirements of current views and practices in language teaching utilizing computer applications and educational technology that can maximize students' language learning. However, it should be noted that technology is only a means for language education and teachers have to improve their capacity to make use of technology in language teaching. Vocabulary is one component of language learning. The conventional way of selecting and teaching vocabulary may place much teaching burden on the teachers because they have to rely on intuition to select difficult words. The ease and convenience offered by the Vocabulary Profile may help alleviate some of the teachers' teaching burden in selecting vocabulary items that are appropriate to the students' current knowledge of English.

\section{REFERENCES}

Al-Maini, Y. H. (2013) Issues in integrating information technology in learning and teaching EFL: the Saudi experience. Merit Research Journal of Education and Review. 1 (5), 107-111.

Ananiadou, K. and Claro, M. (2009). $21^{\text {st }}$ Century skills and competencies for new millennium learners in OECD countries. OECD Education Working Papers, No.41, 4-33, OECD Publishing. Http://dx.doi.org/10.1787/218525261154.)

Arikawei, A. R. And Pelesai, A. N. (2014) Capacity building and challenges of compliance with global best practices in labour-management relations in Bayelsa State. Journal of Education and Practice. 5 (16), 112-117.

Bybee, J. L. (2002). Word frequency and context of use in the lexical diffusion of phonemically conditioned sound change. Language Variation and Change, 14, 261290.

Chinnery, G. M. (2014) A framework for integrating the internet into ELT. English Teaching Forum, No.1, 2-13.

Cobb, T., 2010. Learning about language and learners from computer programs. Reading in a Foreign Language, 22, 181e200. ).

Eckerth, J. and Tavakoli, P. (2012). The effects of word exposure frequency and elaboration of word processing on incidental L2 vocabulary through reading. Language Teaching Research, 16 (2), 227-252.

Graves, M. (2000). A vocabulary program to complement and bolster a middle-grade comprehension program. In B. Taylor, M. Graves, \& P. van den Broek (Eds.), Reading 
for meaning: Fostering comprehension in the middle grades. Newark, DE:

International Reading Association.

Hirsch, E.D. (2003). Reading comprehension requires knowledge of words and the world. American Educator, Spring. American Federation of Teachers.

House, J. (2012) English as a lingua franca and linguistic diversity. Journal of English as a Lingua Franca, 1(1), 173-175. http://dx.doi.org/10.1515/jelf-2012-0008.

Huang, J. (2010). Grammar instruction for adult English language learners: a task-based learning framework. Journal of Adult Education. 39(1), 29-37.

Hunt, A. \& Beglar, D. (2002). Current research and practice in teaching vocabulary. In J.C. Richards \& W.A. Renandya (Eds.) Methodology in language teaching: An anthology of current practice, (pp.254-266), Cambridge: Cambridge University Press.

Hunt, A. and Beglar, D. (2005). A framework for developing EFL reading vocabulary. Reading in a Foreign Language, 17, 23-59.

Information, media and technology skills (2014). Retrieved from The Partnership for $21^{\text {st }}$ Century Skills website: http://www.p21.org.

Kimura, K. (2013) Editor's note: Issues for language education leaders in Asia. Language Education in Asia, 4(1), 1-4.

Kirkpatrick, A. (2010) English as a lingua franca in ASEAN: A multilingual model. Bristol, England: Multilingual Matters.

Laufer \& Nation, 1995) Vocabulary size and use: Lexical richness in L2 written production. Applied Linguistics, 16, 307322.

Learning and information skills (2014). Retrieved from The Partnership for $21^{\text {st }}$ Century Skills website: http://www.p21.org.

Long, M.H. (1991). Focus on form: A design feature in language teaching methodology. In K.R. Ginsbert and C.R. Kramsch (Eds.), Foreign Language Research in Cross-Cultural Perspectives. Amsterdam: Benjamins.

Meyer, D. (2012). Broadening language learning strategies for Asian EFL students. Language Education in Asia, 3(2), 243-251.

Milton, J. (2009) Measuring second language vocabulary acquisition. Bristol, UK: Multilingual Matters.
Milton, J., 2007. Lexical profiles, learning styles and the construct validity of lexical size tests. In: Daller, H., Milton, J., TreffersDaller, J. (Eds.), Modeling and Assessing Vocabulary Knowledge, (pp. 47-58). Cambridge: Cambridge University Press.

Nation, I. S. P. (2001). Learning vocabulary in another language. Cambridge: Cambridge University Press.

Nunan, D. (2004). Task-based language teaching. Cambridge: Cambridge University Press.

Schmitt, N. (2000) Vocabulary in language teaching. Cambridge: Cambridge University Press.

Schmitt, N. (2008). Instructed second language vocabulary learning. Language Teaching Research, 12, 329-363.

Schmitt, N. (2010). Vocabulary in language teaching. Cambridge: Cambridge University Press.

Sedita, J. (2005). Effective vocabulary instruction. Insights on Learning Disability, 2(1), 33-45.

Stahl, S.A. (1999). Vocabulary development. Newton Upper Falls, MA: Brookline Book

Stroupe, R. (2013) The language educator and globalization: how do we best prepare our learners? Language Education in Asia, 4 (2), 110-121. http://dx.doi.org/10.5746/ LEiA/13/V4/12/A02/Stroupe.

Thanh, L. N. \& Huan, N.B. (2012). Taskbased language learning and student motivation in vocabulary acquisition. Language Education in Asia, 3(1), 106-120.

Webb, S. (2007). The effects of repetition on vocabulary knowledge. Applied Linguistics, 28, 46-65.

Wehmeier, S. (2000). Oxford Advanced Leaner's Dictionary of Current English. $6^{\text {th }}$ Edition: New York. Oxford University Press.

Willis, D. \& Willis, J. (2012). Doing task-based teaching. Oxford: Oxford University Press.

Willis, J. (1996). A Framework for task-based learning. Harlow: Addison Wesley Longman.

Zheng, Y. (2012). Exploring long-term productive vocabulary development in an EFL context: the role of motivation. System, 40, 104-119. 
Astika, Profiling the vocabulary of news texts: capacity building for language teachers ...

\title{
APPENDIX 1
}

Sample Text form VOA website

\author{
First Aid: What to Do Until Medical Help Arrive \\ http://learningenglish.voanews.com/content/first-aid-cpr-defibrillator/1946462.html. \\ Retrieved July 1, 2014
}

I'm Mario Ritter. Today, Bob Doughty and Pat Bodnar provide a short guide to first aid. Doctors in hospital emergency rooms often see accidental poisonings. A frightened parent arrives with a child who swallowed a cleaning liquid. Or perhaps the harmful substance is a medicine. Or it might be a product meant to kill insects. These are common causes of accidental poisoning.

In cases like this, seek medical help as soon as possible. Save the container of whatever caused the poisoning. And look on the container for information about anything that stops the effects of the poison.

Save anything expelled from the mouth of the victim. That way, doctors can examine it.

In the past, some people forced poisoning victims to empty the stomach. They used a liquid -- syrup of ipecac -- to do this. But a leading medical organization no longer advises parents to keep syrup of ipecac. The American Academy of Pediatrics says some poisons can cause additional damage when they come back up the throat.

Millions of people know how to give abdominal thrusts to save a person choking on something trapped in the throat.

The American Red Cross says a rescuer should first hit the person on the back five times between the shoulder bones. These back blows may ease the choking. If the airway is still blocked, the Red Cross suggests pushing hard five times along the victim's abdomen. The abdomen is the area between the chest and the hipbones.

You can do these abdominal thrusts by getting directly behind a sitting or standing person. Put your arms around the victim's waist. Close one hand to form a ball. Place it over the upper part of the stomach, below the ribs. Place the other hand on top. Then push forcefully inward and upward. Repeat the abdominal thrusts until the object is expelled from the mouth.

For someone in late pregnancy or who is very fat, place your hands higher than with normal abdominal thrusts. Place the hands at the base of the breastbone -- just above the place where the lowest ribs join. Then begin pushing, as with other victims.

The American Heart Association suggests another method in this case. The group advises chest thrusts instead of abdominal thrusts. For chest thrusts, put your arms under the victim's arms and your hands on the center of the victim's chest.

Even if you are the person choking, you can still help yourself. Place a closed hand over the middle of your abdomen just above your waist. Take hold of that hand with your other hand. Find a hard surface like a chair and rest your body on it. Then push your closed hand in and up.

Red Cross experts say taking these steps can save many lives. But they also say abdominal thrusts are not for people who have almost drowned. They say using the method could delay other ways to restart breathing in the victim. 
CPR is cardiopulmonary resuscitation. It forces air into the lungs and pumps blood and oxygen to the brain. Doctors say CPR greatly increases the chances that a person whose heart stops will survive. It increases the chances that he or she will suffer little or no brain damage.

The American Heart Association suggests two ways of helping. One combines the use of hands to pump the victim's chest with rescue breathing. The other method is called "Hands-Only CPR."

"Hands-Only" is for people who are unwilling or unable to perform rescue breathing. Some people fear infection. Others say they are afraid of making the patient worse.

But an expert in emergency medicine says a person cannot be worse than dead. Dr. Michael Sayre works at Ohio State University. He strongly urges people in contact with a victim to take action.

The American Heart Association tells how to take that action. It says you can recognize a person needing CPR because the person has collapsed. He or she is unconscious -- unable to communicate or react to surroundings or speech. His or her skin has lost color. The person is not breathing. If such conditions describe the situation, chances are the heart has stopped beating.

You should act by calling for help, or sending someone else. Even if you cannot do mouth-to-mouth rescue breathing, you can perform Hands-Only CPR. You can do chest compressions that help to keep blood flowing to the brain, heart and other organs.

To perform the compressions, place one hand over the other and press firmly on the center of the victim's chest. Push down about five centimeters. Aim for 100 compressions each minute. Dr. Sayre says you do not need a measuring stick or a timing device.

If the heart does not start beating, continue with chest compressions until help arrives. For a choking victim who is unconscious with no heartbeat, clear the airway first. Then do chest compressions.

Dr. Sayre suggests that medical workers do both the breathing method and chest compressions. He says some victims, including babies, need the mouth-to-mouth breathing with the compressions. Still, the doctor says it is better to do just chest compressions than to do nothing. CPR is not difficult to learn. Many organizations teach it.

Most CPR training now includes how to use an automated external defibrillator, or AED. Defibrillators use electric shocks to correct abnormal heartbeats that can lead to sudden death. Such devices are found increasingly in public places like airports, restaurants and office buildings. A recorded voice on the AED guides the user. The voice provides detailed information about what to do.

The defibrillator of today has developed from the first defibrillators. Medical historians say the devices appeared late in the 19th century.

In the 1920s, American Claude Beck performed the first surgical operations to repair damaged hearts. Dr. Beck worked at what is now called Case Western Reserve University School of Medicine in Ohio.

Another doctor, Carl J. Wiggers, had kept laboratory animals with heart stoppage alive by massaging their hearts. Then he followed this rubbing with electrical defibrillation. This led Claude Beck in his efforts to help return normal heart actions to human patients.

In 1947, Dr. Beck saved a patient with a defibrillator device for the first time. The doctor's success led others to further develop the method and device. Today small, moveable AED's can identify heart rhythms and produce electricity to treat victims of heart stoppage. 
Astika, Profiling the vocabulary of news texts: capacity building for language teachers ...

Bacteria can enter the body through even the smallest cut in the skin. So medical experts advise people to treat all wounds. Clean the cut with soap and water. Then cover the wound while it heals.

The Mayo Clinic health centers suggest several steps if bleeding is severe. First, if possible, have the person lie down and raise the legs. Remove dirt from the wound and press on it with a clean cloth or piece of clothing. If you cannot find anything clean, use your hand.

Keep putting pressure on the wound until the bleeding stops or medical help arrives. Do not remove the cloth if the blood comes through it. Instead, put another cloth on top and continue pressure. If the bleeding does not stop with direct pressure, put pressure on the artery that carries blood to the wound.

In the past, people were advised to stop severe bleeding with a tourniquet. This device is made with a stick and a piece of cloth or a belt. But experts now say tourniquets are dangerous because they can crush blood passages and nerves.

If a wound seems infected, let the victim rest. Physical activity can spread the infection. Treat the wound with a mixture of salt and water until medical help arrives. Add nine and one-half milliliters of salt to each liter of boiled water. Place a clean cloth in the mixture and then put the cloth on the wound. But be sure not to burn the skin.

To learn more about first aid, ask a hospital or organization like a Red Cross or Red Crescent Society for information. Training may be offered in your area.

If you know first aid methods, you can be calmer and more helpful in case of emergency. This Science in the News program was written by Jerilyn Watson. Our producer was June Simms. Your announcers were Bob Doughty and Pat Bodnar. I'm Mario Ritter. Listen again next week for more news about science on the Voice of America. 


\section{APPENDIX 2}

\section{Word Frequency Groups of the Text}

\section{K1 words - first 1000-word group}

act action activity add additional all almost also another appeared around ask back begin better body buildings called calling carries case cases center centers child clear come comes conditions continue could dead death describe develop developed difficult effects even find followed forced forcefully forces form found front further getting give greatly group half hand hands help helpful helping higher hold includes including increases increasingly just keep kept know late lead leading learn learning led let lie like little lives longer look lost lowest made making meant might minute more most need needing nothing now number numbers offered office often one only other others part people perhaps person place places possible produce producer product provide provides public put putting return rooms say says school see seems sending several shows sitting small smallest society soon speech standing start state still stop stopped stops students such suggest suggests sure take taking tells time times today unable use used user using very voice water way ways week worked workers works written again air along animals apply arms arrive arrives association ball base bleeding blood blows both burn cause caused causes chances close closed color common container content cover cross cut dangerous detailed direct directly doctor doctors efforts enter fear first five flowing former gate hard heart hearts human join kill listen measuring middle millions mouth news nine object operations organization organizations past piece press pressure raise re recognize recorded red reserve rest salt save saved science short shoulder situation spread steps strongly substance success suffer surface teach through top training two university unwilling western wound wounds

\section{K2 word - second 2000-word group}

accidental advise advised advises afraid aim alive babies beating belt blocked boiled bones brain breathing century chair chest clean cleaning cloth clothing combines correct crush damaged delay dirt drowned ease electric electrical electricity empty examine fat firmly frightened guide guides harmful heals health hit hospital information insects inward legs liquid lungs medicine mixture organs parent parents passages patient perform performed poison poisoning poisons program pump pumps push repair repeat rescue restaurants rubbing severe shocks skin soap stick stomach sudden swallowed throat trapped treat unconscious upper upward urges waist worse

\section{Academic-word group}

abnormal academy aid area automated collapsed communicate contact demonstrate device devices expert experts external file identify medical method methods normal physical react remove seek survive

\section{Off-List word group}

abdomen abdominal airports airway announcers artery bacteria beck berlin bob breastbone calmer cardiopulmonary carl centimeters choking clinic com compressions crescent defibrillation defibrillator defibrillators doughty dummy expelled heartbeat heartbeats hipbones historians html http infected infection ipecac kit laboratory liter massaging mayo milliliters moveable nerves oxygen paramedics pat patients pediatrics photo poisonings pregnancy rescuer resuscitation rhythms ribs stoppage surgical surroundings syrup thrusts timing tourniquet tourniquets victim victims 